\title{
Growth and Yield Responses of Three Sweet Corn (Zea mays L. var. Saccharata) Varieties to Local-based Liquid Organic Fertilizer
}

\author{
Fahrurrozi $^{\#}$, Zainal Muktamar ${ }^{*}$, Dwatmadji ${ }^{1}$, Nanik Setyowati ${ }^{\#}$, Sigit Sudjatmiko ${ }^{\#}$, Muhammad Chozin ${ }^{\#}$ \\ \# Agronomy Department, University of Bengkulu, Bengkulu 38371, Indonesia \\ E-mail:fahrurrozi@unib.ac.id;nanik_srg@yahoo.com;s1g1t_s@yahoo.com; m_chozin@hotmail.com \\ * Soil Science Department, University of Bengkulu, Bengkulu 38371, Indonesia \\ E-mail:muktamar1959@yahoo.com \\ ${ }^{1}$ Animal Production Department, University of Bengkulu, Bengkulu 38371, Indonesia \\ E-mail:dwatmadji2008@yahoo.com
}

\begin{abstract}
Solid organic fertilizing for organically sweet corn production should be combined with foliar application to improve fertilizing effectiveness. Each sweet corn variety had different response to particular liquid organic fertilizer (LOF). This experiment aimed to determine growth and yields of three sweet corn varieties to local-based LOF was conducted at CAPS research station (950 m above sea level) from March to June 2015, arranged in a factorial completely randomized block design with three replicates. The first factor was three sweet corn varieties, i.e. Talenta, Jambore and Asian Honey, and the second factor was five LOF concentrations, i.e. $0,25,50,75$, and $100 \mathrm{ppm}$, respectively. Results indicated that sweet corn varieties significantly affected plant height, plant leafarea, root fresh-weight, weight of husked ears, weight of unhusked ears, but did not affect diameter of unhusked ear and shoot freshweight. LOF concentrations did not affect all observed parameters. So did the interaction between varieties and LOF concentrations, except on shoot fresh-weight. Asian Honey variety had the highest plant height, plant leaf-area, roots fresh-weight, weight of hussked ears, and weight of unhusked ears. There were no different in plant diameter and shoot fresh weight among the tested varieties. Further research should be focused on the use of higher concentration of local-based LOF to provide effective complementary organic fertilizing in sweet corn production.
\end{abstract}

Keywords — organic sweet corn; variety responses; liquid organic fertilizer.

\section{INTRODUCTION}

Sweet corn (Zea mays L. var. Saccharata) has been widely considered more beneficial than maize production due to the shorter growing seasons and higher cropping index, which later suppresses production costs and eventually increases farmers' income. In addition, its economic values might be double when it is organically grown due to increasing consumer's demands and limited product availability. It is estimated that the retail values of organic industries by the year of 2015 around US $\$ 100$ billion, more than threefold higher than in 2005 which was accounted for US\$30 billion [1].

The use of solid organic fertilizer has been widely practiced for nutrient supply in organic sweet corn production. Nevertheless, solid organic fertilizer takes longer time to mineralize than crop life-cycles. i.e. within 90 days only after solid organic fertilizer application, there were only $50 \%$ of its N, P, and K get mineralized [2]. Another report confirmed that most composts mineralized $<10 \%$ of intial $\mathrm{N}$ content in the 4 to 6 months after the application into the soil [3]. Research conducted [4] concluded that compost application has a residual effect on the soil nutrient and sweet corn yield. This slow-release characteristic endorses the application of liqud organic fertilizer (LOF) through leaves to fulfill nutrient required for organic sweet corn production. Foliar application is very effective to support growth and yield of maize plants [5].

Previous research concluded that the quality of LOF, i.e. nutrient compositions, is determined by type of raw material, decomposer microorganisms, and the production process [6]. Proper organic vegetable production is eventually conducted in a closed production system. Organic vegetable production is a system approach, where the production was intentionally designed to promote biodiversity, biological cycles, and soil biological activities [7]. The use local materials, therefore, is an essential part of organic vegetable production practices. 
Plant parts, local microorganims as well as plant and animal wastes available around the production areas should be further incorporated in LOF production. Researchers at Closed Agriculture Production Systems Research Center, Faculty of Agriculture University of Bengkulu have developed local-based LOF, composed from topsoil, cattle manure, weed (Tithonia diversifolia (Hamsley) A. Gray), effective microorganism, urine of cattle, and water [8].

Effective foliar application of fertilizer is determined by the crop species, fertilizer form, concentration, frequency of application and the stage of plant growth [7]. Genetic factor also determines the successfulness of organic vegetable production, such as in wheat, tomato, broccoli [9], and in cowpea [10]. Variuos effects of local-based LOF have been previously documented in many vegetables, such as in lettuce [11], [12], Chinese green cabbage [13], cauliflower [14], kaelan [15], potato [16], tomato [17], sweet corn [18] and pechay plants [19].

This research aimed to determine (1) the optimum concentration of local-based LOF for growth and yield of organic sweet corn production and (2) the most reponsive sweet corn variety to local-based LOF.

\section{MATERIALS AND METHODS}

This experiment was conducted at CAPS research station (950 $\mathrm{m}$ above sea level) from March to June 2015, arranged in a factorial completely randomized block design with three replicates. The first factor was three sweet corn varieties, i.e. Talenta, Jambore and Asian Honey, and the second factor was five LOF concentrations, i.e. 0, 25, 50, 75, and $100 \mathrm{ppm}$.

Local-based LOF was made of $10 \mathrm{~kg}$ cattle's feices, 201 cattle's urine, $5 \mathrm{~kg}$ of topsoil, $10 \mathrm{~kg}$ of Tithonia diversifolia (Hamsley) A. Gray), 201 solution of 24-hour incubated 20

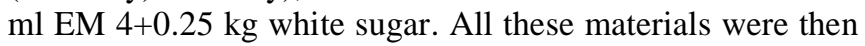
mixtured and added with water in the blue plastic container to reach a volume of 2001 and aerobically fermented for three weeks [8].

Experimental site was cultivated, harrowed and 15 soilbeds of $5 \mathrm{mx} 1 \mathrm{~m}$ in each block were constructed two weeks befor planting. The experimental plot were separated by $0.5 \mathrm{~m}$ within the block and $1 \mathrm{~m}$ between the blocks. Sweet corn seeds were planted at a spacing of $0.7 \mathrm{~m} \times 0.2 \mathrm{~m}$. A week before planting, each soilbed was fertilized with 7.5 $\mathrm{kg}$ of vermicompost (equals to $15 \mathrm{ton} / \mathrm{ha}$ ). Manual control of weeds were bi-weeekly controlled. At the time of weeding, soil around the stem was raised to prevent up-rooting.

Each plant received 25, 25, 50, 100, 150, 250 and $250 \mathrm{ml}$ LOF, respectively at $2,3,4,5,6,7$ and 8 weeks after planting, respectively. Application was conducted during calm day and no rain using knapsack sprayer. Sweet corns were harvested at 70 days after planting. Crop responses to treatments were measured by means of plant diameter $(\mathrm{cm})$, plant height $(\mathrm{cm})$, plant leaf area $\left(\mathrm{cm}^{2}\right)$, shoot fresh weight $(\mathrm{g})$, weight of husked ear $(\mathrm{g})$, length of unhusked ear $(\mathrm{cm})$, weight of unhusked ear $(\mathrm{g})$, and diameter of unhusked ear (cm). Analysis of variances were caculated using SAS 9.1.3. Means of varieties' respsonses were compared using Least Significantly Different Test at $95 \%$ level of confidence.

\section{RESULT AND DISCUSSION}

Sweet corn varieties significantly affected plant height, plant leaf-area, root fresh-weight, weight of husked ears, weight of unhusked ears, but did not affect diameter of unhusked ear and shoot fresh-weight (Table 1). However, LOF concentrations did not affect all observed parameters. So did the interaction between varieties and LOF concentrations, except on shoot fresh-weight.

Asian Honey variety had the highest plant height, plant leaf-area, root fresh-weight, weight of husked ears, weight of unhusked ears compared to other varieties (Table 2). There were no different in plant diameter and shoot fresh weight among the tested varieties. Among the tested varieties, it was generally concluded the Asian Honey was the best, followed by Talenta and Jambore variety. Previous report has documented that genetic factor determined crop responses to LOF [6]. Researchers also developed particular variety of organically grown vegetables, such as wheat, tomato, broccoli [9] and cow pea [10].

This experiment indicated that the use of LOF did not influence growth and yield of sweet corn (Table 1). The effects of LOF to all observed parameters are presented in Table 3. This finding was not similar to previously reported where LOF concentration significantly effect, for example, the weight of husked ears [20] and unhusked ear [21] of sweet corns. Since effectiveness of crop responses to LOF is also determined by its concentration [7], it is presumably that LOF concentration used in this experiment was not sufficient enough to support growth and yields of sweet corn. Aaor laboratory analysis indicated that LOF used in this experiment contained $3.36 \%, 146 \mathrm{ppm}$, and $0.0325 \%$ of $\mathrm{N}$, $\mathrm{P}$, and $\mathrm{K}$, respectively. Nitrogen content of this LOF complied with Indonesian Standardization Board (SNI 197030-2004) for organic fertilizer where total $\mathrm{N}$ should be $>0.4 \%$. However, this was not true for the case of $\mathrm{P}$ and $\mathrm{K}$ which must be $>0.10 \%\left(\mathrm{P}_{2} \mathrm{O}_{5}\right)$ and $>0.20 \%\left(\mathrm{~K}_{2} \mathrm{O}\right)$, respectively. Low content of $\mathrm{P}(146 \mathrm{ppm})$ and $\mathrm{K}(0.0325 \%)$ might have presumably limited LOF effects on sweet corn growth and yields. Our results was generally lower than previously reported [20] where the length of unhusked ears, diameter of unhusked ears, and weight of unhusked ear were $19.7 \mathrm{~cm}, 4.6 \mathrm{~cm}$ and $219.2 \mathrm{~g}$, respectively. The different might be due to the nature of LOF used in their experiments. These features, however, were somehow comply with variety descriptions of Talenta sweet corn (length of unhusked ear, weight of husked ear and diameter of unhusked ear were 19.7-23.5 cm, 221.2-336.7 $\mathrm{g}$ and 4.5-5.4 $\mathrm{cm}$, respectively). There were two major components of this local LOF used in this experiment, i.e., cattle's feices and green mass of Tithonia diversifolia (Hamsley) A. Gray). Manipulating these two components would be one of possible way to have better nutrient compositions of LOF that will further increase growth and yields of sweet corn. Another way that might be possible to have better effects of LOF on growth and yields of sweet corn is by applying higher concentration. Applying higher LOF concentration, however, might be carefully implemented since higher concentration of LOF could delay nutrient uptake by plant, i.e., Chinese mustard [22]. 
Another reason might be related to less effective of LOF to promote growth and yield of sweet corn in this experiments was due to the absence of surfactant during the application of LOF. The use of surfactant was designed to improve liquid foliar fertilizing [23]. The use of surfactant has been reported to somehow improve muskmelon quality [24]. Less response of sweet corns to LOF might be related to the fact that this crop has narrow leaf morphology, since foliar fertilization is more effective in broad leaves than narrow leaves [25]. Our previous reports confirmed that the use of LOF through foliar applications did not significantly improve yields of carrots, a narrow leaf crop [8]. The use of local based LOF has been reported to successfully increase yields of broad-leaf vegetables such as in tomato [17], pechay plant [19] and marrow [25].

There were interaction effects between variety an LOF concentration in growth and yields of sweet corn, except in shoot fresh weight (Table 1). However, Asian Honey variety received 100 ppm LOF generally had better growth compared to other combinations (Table 4). Shoot fresh weight of Asian Honey received $100 \mathrm{ppm}$ and Jambore received $0 \mathrm{ppm}$ were the highest among other treatment combinations, although it was not significantly different with those of Talenta $50 \mathrm{ppm}$, Talenta $75 \mathrm{ppm}$, Talenta $100 \mathrm{ppm}$, Jambore 25 ppm, Jambore 75 ppm, Asian Honey 25 ppm, and Asian Honey $75 \mathrm{ppm}$. The lowest fresh weight was attributed to Talenta $0 \mathrm{ppm}$, Talenta $25 \mathrm{ppm}$, Jambore 50 ppm, Jambore $100 \mathrm{ppm}$, Asian Honey 0 ppm and Asian Honey $50 \mathrm{ppm}$. It seemed that these significances were not proportionally to weights of husked ear and unhusked ear. Growth disturbances during the later course of sweet corn development might have brought about such phenomenon.

These results confirmed previous results that effectiveness of use of organic fertilizers was also determined by crop species and LOF concentration [7]. This finding also implied that there was a need to develop organic vegetable, including sweet corn, variety to have successfull organic vegetable production. Indeed, our colleagues have been developing a breeding program to find superior variety of sweet corn for organically grown in our experimental site since 2012. This program has successfully identified 7 promising genotypes (out of 18 genotypes) that will be further screened for organic sweet corn variety. It is expected by the year of 2018, a suitable hybrid for closed production system is successfully released to the farmers.

\section{CONCLUSIONS}

The concentration of tithonia-based liquid organic fertilizer did not increase growth and yields of organically grown sweet corn. Sweet corn of Asian Honey had the best responses to local-based liquid organic fertilizer, followed by Talenta and Jambore.

\section{ACKNOWLEDGMENT}

Sincerely thank to Directorate General of Higher Education, Ministry of Culture and Education, Indonesia for financing this project through 2014 Fundamental Research Scheme. Acknowledgement is also extented to CAPS of Faculty of Agriculture, University of Bengkulu for providing lands for field experiments.

\section{REFERENCES}

[1] R. Neeson. Going Organic Vegetable Production. A guide to convert organic production. RIRDCS. Australian Government. 2007. 118 pages.

[2] H.D. Foth and B.G. Ellis, B. G. Soil Fertility. 2nd Ed. Lewis Publishers. Tokyo. 1997. 316 pages

[3] T.K. Hartz, J.P. Mitchell and C. Giannini. Nitrogen and carbon mineralization dynamics of manures and composts. 2000. HortScience. 35:209-212.

[4] T.L. Jackson, W. Brinton, D.T. Handley, M. Hutchinson, and M. Hutton, M. 2013. Residual effects of compost applied to sweet corn over two crop seasons. Journal of the NACAA (National Association of County Agricultural Agents). Volume 6(1). Cited on March 14th, 2015 from www.nacaa.com/journal/index.php?jid=222

[5] Amanullah, K.M. Kakar, A. Khan, I. Khan, Z. Shah and Z. Hussain Growth and yield response of maize (Zea mays L.) to foliar NPKfertilizers under moisture stress condition. Soil Environments. 2014. 33(2): 116-123.

[6] G. Brust, D. S. Egel, and E.T. Maynard. Organic Vegetable Production. Purdue University Cooperative Extension Service. 2003. Bulletin \# 316.

[7] D. Haytova. A Review of Roliar Fertilization of Some Vegetable Crops. Annual Review and Research in Biology. 2013. (4):455-465.

[8] Fahrurrozi, Z. Muktamar, N. Setyowati, S. Sudjatmiko and M.Chozin. Evaluation of Tithonia-enriched liquid organic fertilizer for organic carrot production. Technology. 11(8):1705-1712.

[9] E.T. Lammerts van Bueren, S.S. Jones, L. Tamm, K.M. Murphy, J.R. Myers, C. Leifert and M.M. Messmer. The need to breed crop varieties suitable for organic farming, using wheat, tomato and broccoli as examples: A review. Wageningen Journal of Life Sciences. 2011. 58:193-205

[10] D.W. Taura and M.S. Fatima. Effects of organic and inorganic fertilizers on the vegetative and reproductive parts of some selected varieties of cowpea. African Journal of General Agriculture. 2008. 4(2):79-86.

[11] Surtinah. Pemberian Pupuk Organik Super Natural Nutrition (SNN) pada Tanaman Selada ( Lactuca sativa L. ) di Tanah Ultisol. Fakultas Pertanian Unilak Pekan Baru. Ilmiah Pertanian. 2009. 6 (1):20-25. [in Indonesian Language]

[12] N. Darmayanti, N. Marlina, E. Hawayanti. Pengaruh Jenis Pupuk Organik Cair dan Takaran Pupuk Organik Plus terhadap Pertumbuhan dan Produksi Tanaman Selada (Lactuca sativa L.) pada Sistem Budidaya Vertikultur. Klorofil. 2012. 7(2):77-80. [in Indonesian Language]

[13] F. J. Nasution, L. Mawarni dan Meiriani. Aplikasi Pupuk Organik Padat dan Cair dari Kulit Pisang Kepok untuk Pertumbuhan dan Produksi Sawi (Brassica juncea L.). Online Agroekoteknologi. 2014. 1 (3):1029 -1037. [in Indonesian Language]

[14] L. Gomies, H. Rehatta dan J. Nandissa. Pengaruh Pupuk Organik Cair RI1 terhadap Pertumbuhan dan Produksi Tanaman Kubis Bunga (Brassica oleracea Var. Botrytis L.). Agrologia. 2012. 1(1):13-20 [in Indonesian Language].

[15] P. Sinaga, Meiriani dan Y. Hasanah. Respons Pertumbuhan dan Produksi Kailan (Brassica oleraceae L.) pada Pemberian Berbagai Dosis Pupuk Organik Cair Paitan (Tithonia diversifolia Hemsl.) Gray). Online Agroekoteknologi. 2014. 2(4):584-1588. [in Indonesian Language]

[16] S. Parman. Pengaruh Pemberian Pupuk Organik Cair terhadap Pertumbuhan dan Produksi Kentang (Solanum tuberosum L.). Buletin Anatomi dan Fisiologi. 2007. 15(2):21-31. [in Indonesian Language]

[17] Z. Zhai, D.L. Ehret, T. Forge, W. Lin, M. Dorais, and P.A. Papadopoulos. Organic Fertilizers for Greenhouse Tomatoes: Productivity and Substrate Microbiology. HortScience. 2009. 44 (2): 800-809.

[18] M. S. Pasaribu, W.A. Barus dan H. Kurnianto H. Pengaruh Konsentrasi dan Interval Waktu Pemberian Pupuk Organik Cair (Poc) Nasa Terhadap Pertumbuhan dan Produksi Jagung Manis (Zea Mays Saccharata Sturt). Agrium. 2011. 17(1):46-52. [in Indonesian Language]

[19] C. Dela-Pena, .D. L. I. Bartolome and T. P. Banwa. The potential of Tithonia diversifolia (Wild Sunflower) as organic foliar fertilizer. 2013. European Scientific Journal. 4:465-468. 
[20] Syafruddin, Nurhayati dan R. Wati. Pengaruh Jenis Pupuk Terhadap Pertumbuhan dan Hasil Beberapa Varietas Jagung Manis. J. Floratek. 2012. 7:107-114. [in Indonesian Language]

[21] Syofia I, A. Munar dan M. Sofyan. Pengaruh Pupuk Organik Cair Terhadap Pertumbuhan dan Hasil Dua Varietas Tanaman Jagung Manis (Zea Mays Saccharatasturt). Agrium . 2014. 18 (3) : 208-218 [in Indonesian Language].

[22] G.A. Sopha, and T.S. Uhan. Application of liquid organic fertilizer from city waste on reduce urea application on Chinese mustrad (Brassica juncea L.) cultivation. 2013. AAB Bioflux. 5:39-44. http://aab.bioflux.com.ro

[23] P.J. Holloway and D. Stock. Factors affecting the activation of foliar uptake of agrochemicals by surfactants. In: D.S. Karsa (ed.),
Industrial application of surfactants II. London, Royal Society of Chemistry. Special publication. 1990. 77. pp. 303-337.

[24] G.E. Lester, J.L. Jifon and D.J. Makus. Supplemental foliar potassium applications with or without a surfactant can enhance netted muskmelon quality. 2006. HortScience. 41(3):741-744

[25] [24] J. Hagin, and B. Tucker. 1982. Fertilization of Dryland and Irrigated Soil. Springs-verlag, Berlin. Helderberg Inc, Germany.

[26] [25] D. Kostova, D. Haytoya, and D. Mechandjiev. Effect of type and method of fertilization on marrows (Cucurbita pepo L.) yield and fruit quality. American Journal of Experimental Agriculture. 2014. 4(4):376-383.

TABLE I

F>PROB. VALUES OF SOURCE OF VARIANCES OF PLANT DIAMETER (PD), PLANT HEIGHT (PH), PLANT LEAF AREA (PLA), SHOOT FRESH WEIGHT (SFW), WEIGHT OF GREEN EAR (WGE), LENGTH OF EAR (LE), WEIGHT OF DEHUSK EAR (WDE), DIAMETER OF DEHUSK EAR (DDE) OF SWEET CORNS

\begin{tabular}{|l|l|l|l|l|l|l|l|l|l|}
\hline \multirow{2}{*}{ Source of variances } & \multicolumn{9}{|c|}{ Variables (F> Prob 5 \%) } \\
\cline { 2 - 11 } & PD & PH & PLA & SFW & RFW & WGE & LE & WDE & DDE \\
\hline Model & 0.0444 & 0.0001 & 0.0001 & 0.0577 & 0.0595 & 0.0069 & 0.0056 & 0.0007 & 0.0072 \\
\hline Variety & 0.6235 & 0.0001 & 0.0326 & 0.4684 & 0.0018 & 0.0001 & 0.0001 & 0.0001 & 0.0001 \\
\hline Concentration & 0.5166 & 0.1018 & 0.4202 & 0.5000 & 0.2206 & 0.3567 & 0.5855 & 0.2456 & 0.3769 \\
\hline Variety*Concentration & 0.0822 & 0.1049 & 0.0452 & 0.0243 & 0.4151 & 0.4757 & 0.9187 & 0.3455 & 0.8477 \\
\hline Block & 0.0052 & 0.0687 & 0.0001 & 0.1122 & 0.7702 & 0.0385 & 0.0032 & 0.0303 & 0.0096 \\
\hline Coefficient Variation & 8.63 & 5.05 & 13.83 & 22.67 & 34.41 & 21.32 & 11.30 & 23.80 & 8.12 \\
\hline Linear & 0.2141 & 0.0183 & 0.4045 & 0.7973 & 0.2018 & 0.3528 & 0.2357 & 0.1785 & 0.1289 \\
\hline Quadratic & 0.7940 & 0.7364 & 0.9591 & 0.2192 & 0.2940 & 0.2909 & 0.4846 & 0.2180 & 0.3812 \\
\hline Cubic & 0.2889 & 0.8304 & 0.9547 & 0.7723 & 0.6620 & 0.2011 & 0.3623 & 0.2976 & 0.4135 \\
\hline
\end{tabular}

TABLE II

EFFECT OF VARIETIES ON PLANT DIAMETER (PD), PLANT HEIGHT (PH), PLANT LEAF AREA (PLA), SHOOT FRESH WEIGHT (SFW), WEIGHT OF GREEN EAR (WGE), LENGTH OF EAR (LE), WEIGHT OF DEHUSK EAR (WDE), DIAMETER OF DEHUSK EAR (DDE) OF SWEET CORNS

\begin{tabular}{|c|c|c|c|c|c|c|c|c|c|}
\hline \multirow[b]{2}{*}{ Variety } & \multicolumn{9}{|c|}{ Variables } \\
\hline & $\begin{array}{c}\text { PD } \\
(\mathrm{cm})\end{array}$ & $\begin{array}{c}\mathrm{PH} \\
(\mathrm{cm})\end{array}$ & $\begin{array}{c}\text { PLA } \\
(\mathrm{cm} 2)\end{array}$ & $\begin{array}{c}\text { SFW } \\
(\mathrm{g})\end{array}$ & $\begin{array}{c}\text { RFW } \\
(\mathrm{g})\end{array}$ & $\begin{array}{c}\text { WGE } \\
(\mathrm{g})\end{array}$ & $\begin{array}{c}\mathrm{LE} \\
(\mathrm{cm})\end{array}$ & $\begin{array}{c}\text { WDE } \\
(\mathrm{g})\end{array}$ & $\begin{array}{l}\text { DDE } \\
(\mathrm{cm})\end{array}$ \\
\hline Talenta & $1.71 \mathrm{a}$ & $150 \mathrm{~b}$ & $3560 \mathrm{ab}$ & $189 \mathrm{a}$ & $22.1 \mathrm{~b}$ & $171 \mathrm{a}$ & $15.3 \mathrm{~b}$ & $111 \mathrm{~b}$ & $4.15 \mathrm{~b}$ \\
\hline Jambore & $1.76 \mathrm{a}$ & $151 \mathrm{~b}$ & $3406 \mathrm{~b}$ & $204 \mathrm{a}$ & $18.7 \mathrm{~b}$ & $128 \mathrm{~b}$ & $13.6 \mathrm{c}$ & $77 \mathrm{c}$ & $3.82 \mathrm{c}$ \\
\hline Asian Honey & $1.76 \mathrm{a}$ & $169 \mathrm{a}$ & $3903 \mathrm{a}$ & $209 a$ & $30.3 \mathrm{a}$ & $192 \mathrm{a}$ & $16.8 \mathrm{a}$ & $137 \mathrm{a}$ & $4.45 \mathrm{a}$ \\
\hline
\end{tabular}

Means in the same column followed with the same letter are not significantly different according to Least Significantly Different Test at $5 \%$

TABLE III

EFFECT OF LIQUID ORGANIC FERTILIZER ON PLANT DIAMETER (PD), PLANT HEIGHT (PH), PLANT LEAF AREA (PLA), SHOOT FRESH WEIGHT (SFW), WEIGHT OF GREEN EAR (WGE), LENGTH OF EAR (LE), WEIGHT OF DEHUSK EAR (WDE), DIAMETER OF DEHUSK EAR (DDE) OF SWEET CORNS

\begin{tabular}{|c|c|c|c|c|c|c|c|c|c|}
\hline \multirow[b]{2}{*}{ Concentrations } & \multicolumn{9}{|c|}{ Variables } \\
\hline & $\begin{array}{l}\text { PD } \\
(\mathrm{cm})\end{array}$ & $\begin{array}{c}\mathrm{PH} \\
(\mathrm{cm})\end{array}$ & $\begin{array}{c}\text { PLA } \\
(\mathrm{cm} 2)\end{array}$ & $\begin{array}{c}\text { SFW } \\
(\mathrm{g})\end{array}$ & $\begin{array}{c}\text { RFW } \\
(\mathrm{g})\end{array}$ & $\begin{array}{c}\text { WGE } \\
(\mathrm{g})\end{array}$ & $\begin{array}{c}\mathrm{LE} \\
(\mathrm{cm})\end{array}$ & $\begin{array}{c}\text { WDE } \\
(\mathrm{g})\end{array}$ & $\begin{array}{l}\mathrm{DDE} \\
(\mathrm{cm})\end{array}$ \\
\hline Control & $1.67 \mathrm{a}$ & $151 \mathrm{a}$ & $3458 \mathrm{a}$ & $202 \mathrm{a}$ & $21.5 \mathrm{a}$ & $157 \mathrm{a}$ & $14.8 \mathrm{a}$ & $102 \mathrm{a}$ & $4.04 \mathrm{a}$ \\
\hline $25 \mathrm{ppm}$ & $1.76 \mathrm{a}$ & $154 \mathrm{ab}$ & $3521 \mathrm{a}$ & $189 \mathrm{a}$ & $21.2 \mathrm{a}$ & $163 \mathrm{a}$ & $15.2 \mathrm{a}$ & $104 \mathrm{a}$ & $4.09 \mathrm{a}$ \\
\hline $50 \mathrm{ppm}$ & $1.72 \mathrm{a}$ & $156 \mathrm{ab}$ & $3598 \mathrm{a}$ & $184 \mathrm{a}$ & $21.2 \mathrm{a}$ & $147 \mathrm{a}$ & $14.8 \mathrm{a}$ & $97 \mathrm{a}$ & $4.05 \mathrm{a}$ \\
\hline $75 \mathrm{ppm}$ & $1.78 \mathrm{a}$ & $161 \mathrm{a}$ & $3644 \mathrm{a}$ & $209 \mathrm{a}$ & $26.8 \mathrm{a}$ & $179 \mathrm{a}$ & $16.0 \mathrm{a}$ & $122 \mathrm{a}$ & $4.21 \mathrm{a}$ \\
\hline $100 \mathrm{ppm}$ & $1.77 \mathrm{a}$ & $160 \mathrm{a}$ & $3895 \mathrm{a}$ & $218 \mathrm{a}$ & $28.0 \mathrm{a}$ & $173 \mathrm{a}$ & $15.4 \mathrm{a}$ & $117 \mathrm{a}$ & $4.31 \mathrm{a}$ \\
\hline
\end{tabular}

Means in the same column followed with the same letter are not significantly different according to Least Significantly Different Test at 5\% 
TABLE IV

INTERACTION EFFECT OF VARIETY AND CONCENTRATION OF LIQUID ORGANIC FERTILIZER ON PLANT DIAMETER (PD), PLANT HEIGHT (PH), PLANT LEAF AREA (PLA), SHOOT FRESH WEIGHT (SFW), WEIGHT OF GREEN EAR (WGE), LENGTH OF EAR (LE), WEIGHT OF DEHUSK EAR (WDE), DIAMETER OF DEHUSK EAR (DDE) OF SWEET CORNS

\begin{tabular}{|c|c|c|c|c|c|c|c|c|c|}
\hline \multirow[b]{2}{*}{ Treatment Combinations } & \multicolumn{9}{|c|}{ Variables } \\
\hline & $\begin{array}{c}\text { PD } \\
(\mathrm{cm})\end{array}$ & $\begin{array}{c}\mathrm{PH} \\
(\mathrm{cm})\end{array}$ & $\begin{array}{l}\text { PLA } \\
(\mathrm{cm} 2)\end{array}$ & $\begin{array}{c}\mathrm{SFW}^{*} \\
(\mathrm{~g})\end{array}$ & $\begin{array}{c}\text { RFW } \\
(\mathrm{g})\end{array}$ & $\begin{array}{c}\text { WGE } \\
(\mathrm{g})\end{array}$ & $\begin{array}{c}\mathrm{LE} \\
(\mathrm{cm})\end{array}$ & $\begin{array}{c}\text { WDE } \\
(\mathrm{g})\end{array}$ & $\begin{array}{l}\text { DDE } \\
(\mathrm{cm})\end{array}$ \\
\hline Talenta, 0 ppm & 1.62 & 143 & 3127 & $150 \mathrm{~b}$ & 18.2 & 151 & 14.9 & 96.6 & 4.06 \\
\hline Talenta, $25 \mathrm{ppm}$ & 1.69 & 143 & 3301 & $167 \mathrm{~b}$ & 17.8 & 160 & 15.1 & 100.4 & 4.01 \\
\hline Talenta, $50 \mathrm{ppm}$ & 1.75 & 153 & 3755 & $201 \mathrm{ab}$ & 23.0 & 175 & 15.4 & 115.3 & 4.20 \\
\hline Talenta, 75 ppm & 1.78 & 157 & 3608 & $210 \mathrm{ab}$ & 23.5 & 192 & 16.3 & 128.9 & 4.38 \\
\hline Talenta, 100 ppm & 1.72 & 151 & 4011 & $216 \mathrm{ab}$ & 28.2 & 180 & 15.1 & 114.2 & 4.12 \\
\hline Jambore, 0 ppm & 1.83 & 152 & 3812 & $273 \mathrm{a}$ & 20.3 & 137 & 13.5 & 85.7 & 3.77 \\
\hline Jambore, 25 ppm & 1.83 & 153 & 3572 & $209 \mathrm{ab}$ & 19.5 & 141 & 13.9 & 84.4 & 3.83 \\
\hline Jambore, $50 \mathrm{ppm}$ & 1.76 & 150 & 3406 & $181 \mathrm{~b}$ & 18.1 & 112 & 13.1 & 63.6 & 3.56 \\
\hline Jambore, 75 ppm & 1.75 & 151 & 3275 & $191 \mathrm{ab}$ & 20.3 & 139 & 14.4 & 86.5 & 4.11 \\
\hline Jambore, 100 ppm & 1.62 & 147 & 2965 & $165 \mathrm{~b}$ & 15.5 & 110 & 12.9 & 64.7 & 3.85 \\
\hline Asian Honey, 0 ppm & 1.60 & 159 & 3436 & $183 \mathrm{~b}$ & 25.9 & 182 & 16.2 & 122.7 & 4.29 \\
\hline Asian Honey, 25 ppm & 1.78 & 166 & 3692 & $189 \mathrm{ab}$ & 26.4 & 188 & 16.6 & 128.1 & 4.46 \\
\hline Asian Honey, 50 ppm & 1.65 & 165 & 3632 & $171 \mathrm{~b}$ & 22.5 & 155 & 16.0 & 113.2 & 4.39 \\
\hline Asian Honey, 75 ppm & 1.82 & 174 & 4048 & $227 \mathrm{ab}$ & 36.5 & 205 & 17.3 & 149.5 & 4.45 \\
\hline Asian Honey, 100 ppm & 1.98 & 182 & 4709 & $273 \mathrm{a}$ & 40.3 & 230 & 18.1 & 170.8 & 4.67 \\
\hline
\end{tabular}

* Means in the same column followed with the same letter are not significantly different according to Duncan's Multiple Range Test at 5\% 